\title{
Gagnkvæmur ávinningur fyrirtækja og neytenda af sterkum vörumerkjasamfélögum
}

\author{
Auður Hermannsdóttir og Karen Arnarsdóttir ${ }^{1}$
}

\begin{abstract}
Ágrip
Fyrirtæki eru í auknum mæli farin að beita samfélagsmiðlum sem hluta af markaðstólum sínum, sér í lagi til að efla samskipti við neytendur. Vörumerkjasamfélög eru sérhæfð samfélög, byggð upp á samfélagsmiðlum í kringum félagsleg tengsl fylgjenda ákveðins vörumerkis eða fyrirtækis. Markmið rannsóknarinnar var að kanna hvort vörumerkjasamfélög geti skilað ávinningi bæði fyrir neytendur og fyrirtæki. Rafrænu hentugleikaúrtaki var beitt par sem pátttakendur ( $\mathrm{N}=247)$ tóku afstöðu til ýmissa fullyrðinga sem ætlað var að meta styrk vörumerkjasamfélags, virði fyrir neytendur og tryggð gagnvart fyrirtæki eða vörumerki. Niðurstöðurnar sýna að sterkt vörumerkjasamfélag, par sem upplýsingum er miðlað og ýtt er undir pátttöku meðlima, skapar virði fyrir neytendur. Félagslegt tengslanet peirra styrkist, peir upplifa ávinning af pátttöku og sjá gagn í peim upplýsingum sem miðlað er innan samfélagsins. Niðurstöðurnar sýna að virðið sem neytendur njóta vegna vörumerkjasamfélagsins leiðir til aukinnar tryggðar peirra gagnvart viðkomandi fyrirtæki eða vörumerki. Aukin tryggð skapast ekki eingöngu vegna styrks samfélagsins heldur í gegnum pað virði sem skapast fyrir neytendur. Pessar niðurstöður eru veigamiklar fyrir fyrirtæki og mikilvægt framlag til fræðanna um stjórnun vörumerkjasamfélaga. Líkt og í öđru markaðsstarfi er hér sýnt fram á að útgangspunkturinn parf fyrst og fremst að vera viðskiptavinurinn og pað virði sem skapað er fyrir hann. Sé hugað að auknu virði fyrir viðskiptavini í gegnum pátttöku í vörumerkjasamfélagi er pað líklegt til að leiða til ávinnings fyrir fyrirtæki í formi aukinnar tryggðar.
\end{abstract}

\begin{abstract}
It is increasingly common for organizations to use social media as one of their marketing tools, especially to increase relationship with consumers. Brand communities are specialized communities on social media around the social connections of followers of a specific organization or brand. The purpose of this study was to explore if brand communities can benefit both consumers and organizations. An online convenience sample was used where participants $(\mathrm{N}=247)$ were asked to answer number of statements regarding brand communities' strength, value for consumers and loyalty towards an organization or a brand. The findings show that the benefits consumers gain from participating in a brand community lead to an increased loyalty towards an organization or brand. These findings are important for organizations and an important contribution to research on brand

1 Auður Hermannsdóttir er aðjúnkt við Viðskiptafræðideild Háskóla Íslands og Karen Arnarsdóttir er M.Sc. í markaðsfræði og alpjóðaviðskiptum. Höfundar pakka tveimur ónafngreindum ritrýnum fyrir gagnlegar ábendingar.
\end{abstract}


communities. Like in other marketing activities it is emphasized that consumers and their benefits have to be in central focus. If we focus on added value for consumers through their participation in brand communities it is likely to lead to benefits for organizations through added consumers' loyalty.

JEL-flokkun: M31, M39

Lykilhugtök: Vörumerkjasamfélög, samfélagsmiðlar, vörumerkjatryggð, félagsleg stjórnun viðskiptatengsla, Facebook.

\section{Inngangur}

Markaðssetning snýst ekki lengur aðeins um að ná til fjöldans í gegnum hina hefðbundnu miðla svo sem sjónvarp, útvarp og dagblöð heldur snýst hún í auknum mæli einnig um að skapa tengsl og eiga nánari samskipti við viðskiptavini. Nokkuð er síðan ýmis fyrirtæki fóru að færa áherslur sínar í markaðsstarfi frá pví að vera vöru- eða vörumerkjamiðaðar yfir í að vera viðskiptavinamiðaðar (Reinartz, Krafft og Hoyer, 2004). Í pví felst að leggja áherslu á stjórnun viðskiptatengsla (customer relationship management) par sem litið er á viðskiptavininn sem verðmæti og áhersla lögð á að próa traust samband við hann og hámarka líftímavirði hans fremur en að einblína á einstakar sölur (Ang, 2011; O’Brien, 2011). Мeð auknum tengslum við viðskiptavini gefst tækifæri til að læra bæði um pá og af peim sem leiðir til pess að fyrirtækin verða betur í stakk búin til að skilja hegðun og parfir viðskiptavina sinna. Í kjölfarið geta fyrirtækin sniðið framboð sitt betur að pörfum viðskiptavina og pannig boðið peim enn meira virði sem svo ýtir undir pá tilfinningu hjá viðskiptavinunum að peir séu virtir og mikils metnir (Ang, 2011; O’Brien, 2011). Árangursrík stjórnun viðskiptatengsla leiðir par af leiðandi til ávinnings bæði fyrir fyrirtæki og viðskiptavini.

Samfélagsmiðlar bjóða upp á ýmsar leiðir til að mynda og styrkja tengslin við viðskiptavini (Hanna, Rohm og Crittenden, 2011; O’Brien, 2011) og eru fyrirtæki í auknum mæli farin að beita samfélagsmiðlum sem hluta af markaðstólum sínum (Lee, 2013). Pegar fyrirtæki nota samfélagsmiðla við stjórnun viðskiptatengsla er talað um félagslega stjórnun viðskiptatengsla (social customer relationship management) en hún gengur út á að virkja viðskiptavini í gegnum samfélagsmiðla í peim tilgangi að byggja upp tryggð (Kotadia, 2010). Fyrirtækin eiga pá í samvinnu og gagnvirkum samskiptum við viðskiptavini í peirri von að slíkt skili sér í auknu virði fyrir pá ekki síður en fyrir fyrirtækið (Alkhomes og Alnsour, 2013; Baird og Parasnis, 2011).

Vörumerkjasamfélög (brand communities) eru sérhæfð samfélög sem eru byggð upp á samfélagsmiðlum í kringum félagsleg tengsl fylgjenda ákveðins vörumerkis eða fyrirtækis (Muñiz og O'Guinn, 2001). Pá koma saman á tiltekinni síðu á samfélagsmiðli hinir ýmsu einstaklingar sem hafa áhuga á viðkomandi vörumerki. Раð eina sem einstaklingur parf að gera til að teljast meðlimur í samfélaginu er að tengja sig pví með pví að fylgja eða líka við viðkomandi síðu (Adjei, Noble og Noble 2012). Par geta meðlimir deilt skoðunum sínum og reynslu eða nálgast upplýsingar um vörumerkið. Vörumerkjasamfélög haga sér á margan hátt eins og önnur hefðbundin samfélög en munurinn er pó sá að miðpunktur peirra er söluvara, sem meðlimir ákveða sjálfir að vera í sambandi við (Muñiz og O'Guinn, 2001).

Mörg fyrirtæki hafa kosið að skapa pennan vettvang sem vörumerkjasamfélög eru. Facebook, sem er stærsti samfélagsmiðill heims í dag, hýsir ógrynni slíkra samfélaga (Pöyry, 
Parvinen og Malmivaara, 2013). Ekki nægir eingöngu að stofna vettvanginn heldur parf að sinna samfélaginu, enda getur pað jafnvel verið skaðlegra fyrir fyrirtæki að standa illa að málum pegar kemur að notkun samfélagsmiðla heldur en að sleppa pví alveg (O’Brien, 2011). Ef fyrirtæki ætla á annað borða að vera á samfélagsmiðlum verða pau að vera tilbúin til að pjónusta notendur miðilsins. Раð að safna stórum hópi af fylgjendum leiðir ekki sjálfkrafa til ávinnings. Fyrirtækin verða að vera í stakk búin til að vakta pað sem par fer fram milli einstaklinga innan samfélagsins, svara fyrirspurnum og athugsemdum og vera tilbúin að bregðast við hinu óvænta (Jahn og Kunz, 2012; O’Brien, 2011). Jafnframt er nauðsynlegt að halda síðunni lifandi með alls kyns innleggjum og kalla fram samtal við neytendur. Samkvæmt rannsókn Algesheimer, Dholakia og Herrmann (2005) eru samskiptamiðlar fyrst og fremst góð leið til að dýpka tengslin við viðskiptavini, fremur en leið til að afla nýrra.

Pví hefur stundum verið haldið fram að markaðssetning í gegnum samfélagsmiðla sé ódýr leið í markaðssetningu, en pað má ekki vanmeta pann tíma sem starfsfólk parf að verja í að sinna samfélaginu. Á undanförnum árum hafa komið birst rannsóknir á líklegum ávinningi pess að verja tíma starfsfólks í að halda úti vörumerkjasamfélögum (sjá t.d. Adjei o.fl., 2012; Alkhoms og Alnsour, 2013), hins vegar er pörf á frekari rannsóknum á sviðinu, enda um fremur nýtt markaðstæki að ræða. Til að réttlætanlegt sé fyrir fyrirtæki að verja tíma starfsfólks í að sinna vörumerkjasamfélögum parf að vera ljóst að sú vinna muni skila fyrirtækinu ávinningi. Par sem markmiðið er í mörgum tilvikum að auka tengslin við viðskiptavini er pörf á að kanna hvort pað að halda úti vörumerkjasamfélagi skili sér í auknum tengslum við viðskiptavini, p.e. í aukinni tryggð peirra gagnvart vörumerkinu eða fyrirtækinu. Nokkrar slíkar rannsóknir hafa verið framkvæmdar sem hafa sýnt að vörumerkjasamfélög hafa jákvæð áhrif á tryggð (sjá t.d. Gummerus o.fl., 2012; Jahn og Kunz, 2012). Pörf er pó á frekari rannsóknum til að staðfesta niðurstöður um pennan mögulega ávinning. Rannsókninni er ætlað að auka pekkingu á og styrkja stoðir pessa tiltölulega nýja sviðs innan markaðsfræðanna. Markmið hennar er að kanna hvort vörumerkjasamfélög geti skilað ávinningi bæði fyrir neytendur og fyrirtæki. Kannað verður hvort neytendur njóti aukins virðis af pví að tilheyra samfélagi í formi félagslegs tengslanets, áhuga á pátttöku og upplýsinga um notkun vörunnar/pjónustunnar. Jafnframt verður kannað hvort fyrirtæki njóti ávinnings af vörumerkjasamfélögum í formi aukinnar tryggðar viðskiptavina.

Byrjað verður á að fjalla um hvað felist í faglegri stjórnun vörumerkjasamfélaga. Í kjölfarið verður fjallað um mögulegt virði neytenda af pví að tilheyra slíku samfélagi og svo fjallað um mögulegan ávinning fyrirtækja af pví að ýta undir tryggð í gegnum vörumerkjasamfélög. Fjallað verður um pá aðferðafræði sem beitt var við rannsóknina og að lokum verða niðurstöður settar fram, pær ræddar í samhengi við fyrri rannóknir og velt upp með hvaða hætti fyrirtæki geti nýtt niðurstöðurnar.

\section{Stjórnun vörumerkjasamfélaga}

Pótt flest fyrirtæki séu farin að átta sig á peim tækifærum sem samfélagsmiðlar hafa upp á að bjóða eru fæst sem vita fyllilega hvernig á að fara að pví að nýta pessi tækifæri (Hanna o.fl., 2011) og samtvinna samfélagsmiðla í annað markaðsstarf fyrirtækisins (McCorkindale, 2010). Síður fyrirtækja á samfélagsmiðlum má ekki líta á sem sjálfstæða einingu heldur eru pær hluti af peim skilaboðum sem fyrirtækið lætur frá sér fara og nauðsynlegt að huga að samhæfðum markaðssamskiptum (integrated marketing communication) pegar kemur að samfélagsmiðlum eins og öðrum markaðssamskiptum. Hegðun og gildi verða að vera í 
samræmi við pað sem viðskiptavinurinn pekkir frá öðrum stöðum og upplýsingar pær sömu, sama hvaða miðill er skoðaður (Alkhoms og Alnsour, 2013; Hanna o.fl., 2011; Rosen og Phillips, 2011).

Eins og í öðru markaðsstarfi parf að setja skýr markmið varðandi samfélagsmiðlanotkun. Раð parf að vera skýrt hvers vegna, hvernig og hvenær eigi að nota samfélagsmiðla sem lið í markaðsfærslunni, rétt eins og parf að gera varðandi aðrar markaðsaðgerðir (Schmidt og Ralph, 2011). Auk pess að kynna fyrirtæki og hafa áhrif á ímynd peirra bjóða samfélagsmiðlar upp á nýjar leiðir til að auka pjónustu, virkja neytendur og mynda við pá tengsl. Á síðum fyrirtækja verða til samfélög par sem meðlimir geta átt í beinum gagnvirkum samskiptum við fyrirtæki en einnig sín í milli (Edosomwan, Prakasan, Kouame, Watson og Seymour, 2011; Woodcock, Green og Starkley, 2011). Peir geta pví myndað tengsl við aðra sem deila áhuga á tilteknu vörumerki eða fyrirtæki. Fyrirtækin geta fylgst með hegðun neytenda, fylgst með pví sem peir hafa að segja bæði jákvætt og neikvætt og geta pannig náð að skilja betur viðhorf peirra og tilfinningar (Woodcock o.fl., 2011). Jafnframt hafa fyrirtæki tækfæri til að opna á tiltekna umræðu, fá endurgjöf á vöru, pjónustu eða aðgerðir fyrirtækisins og fá hugmyndir frá neytendum (Gummerus, Liljander, Weman og Pihlström, 2012). Í kjölfarið er hægt að aðlaga vöru og/eða pjónustuframboðið að óskum og pörfum neytenda og jafnvel hægt að endurskoða stefnu eða áherslur fyrirtækja ef talin er ástæða til pess (Woodcock o.fl., 2011). Раð er nauðsynlegt fyrir fyrirtæki að próa með sér færni í að átta sig á hvenær pau eiga að taka pátt í samræðunum og hvenær ekki, stundum er innlegg peirra góð viðbót en á öðrum tímum vilja meðlimirnir fá að eiga tiltekna umræðu sín í milli (Kietzmann, Hermkens, McCarthy og Silvestre, 2011).

Neytendur hafa tækifæri til að móta samfélagið með pví að setja efni inn á síðu fyrirtækisins. Eins geta peir skilið eftir athugasemdir við pað sem aðrir setja á síðuna hvort sem pað eru aðrir notendur eða fyrirtækið sjálft (Pöyry o.fl., 2013). Öll pessi atriði auðvelda fyrirtækjum að fylgjast með og skilja betur parfir viðskiptavina sinna, fylgjast með breytingum á pörfunum og bera kennsl á pær fyrr en ella (Sashi, 2012).

Раð að stofna t.d. Facebook-síðu eða Twitter-síðu gefur fyrirtækjum ekki forskot eitt og sér. Pau verða að halda síðunni virkri og bjóða upp á hluti sem notendur kunna að meta og hafa eitthvert gildi fyrir pá, hvort sem pað er hagnýtt eða til skemmtunar. Annars finnst peim líklega lítill tilgangur í að fylgjast með fyrirtækjunum (Jahn og Kunz, 2012; Vorvoreanu, 2009). Pegar neytendur kjósa að fylgja fyrirtækjum á samfélagsmiðlum með pví að líka við síður peirra, gera peir pað oftast með pað í huga að eiga samskipti við fyrirtækin eða vörumerki peirra með einum eða öðrum hætti. Neytendum finnst að samskipti á Facebook eigi að vera persónuleg, hvort sem pað er við vini, kunningja, fjölskyldumeðlimi eða við fyrirtæki (Vorvoreanu, 2009). Pangað sækja peir skemmtun og afpreyingu og kunna ekki að meta pað að fyrirtæki pröngvi sér upp á pá eða að peir finni sterkt fyrir ópersónulegri beinni markaðssetningu eða söluáherslu (Dekay, 2012; Kwok og Yu, 2012; Vorvoreanu, 2009). Notendum finnst pað einnig fráhrindandi ef fyrirtæki reyna um of að vera "töff“ á Facebook (Vorvoreanu, 2009) eða tilgerðarleg en peim finnst mikilvægt að pau séu heiðarleg (Baird og Parasnis, 2011). Að mati Kwok og Yu (2012) er árangursríkast að koma fram við neytendur á samfélagsmiðlum sem vini og félaga fremur en sem móttakendur markaðsefnis. Рað parf að tala við meðlimi samfélagsins en ekki bara til peirra (Wright, Khanfar, Harrington og Kizer, 2010). Pá eru meiri líkur á að peir upplifi meira virði af samskiptunum og séu tilbúnari til að taka virkari pátt í samfélaginu og pví sem er að gerast hjá fyrirtækinu eða vörumerkinu. Neytendum finnst best að eiga samskipti við fyrirtækin á sínum eigin forsendum (Vorvoreanu, 2009) og ef peir er ekki ánægðir með pau 
samskipti sem fram fara á samfélagsmiðlum er ólíklegra en ella að peir vilji eiga í samskiptum og viðskiptum við fyrirtækið í framtíðinni (Sashi, 2012).

Mikilvægt er að vakta síður fyrirtækjanna vel og fylgjast náið með samfélaginu. Fara parf yfir pað efni sem kemur inn á síðuna og taka tíma í að svara fyrirspurnum og athugasemdum, en slíkt styrkir trú neytenda á sambandinu (Lee, 2013). Pað má hvorki láta síðuna staðna með pví að gleyma að uppfæra hana né má ofnota hana pannig að neytendur fái nóg og fari að hunsa efnið eða hætti jafnvel að fylgja fyrirtækinu á samfélagsmiðlinum (Wright o.fl., 2010). Í pessu purfa fyrirtæki að finna taktinn og pekkja parfir og langanir síns samfélags. Nauðsynlegt er að búa sig undir pá neikvæðni sem ratað getur inn á samfélagssíður fyrirtækja og vera með áætlun um hvernig skuli taka á henni. Ekki er æskilegt að eyða út kvörtunum eða öðrum neikvæðum athugasemdum af síðunum heldur skal reyna að finna lausn á vandamálinu og koma umræðunni í jákvæðan farveg (Dekay, 2012).

Hvort sem fyrirtæki kjósa að taka virkan pátt á samfélagsmiðlum eða ekki er ekkert sem getur stöðvað neytendur í að ræða reynslu sína við aðra á peim vettvangi (Woodcock o.fl., 2011). Hvort sem umfjöllunin er jákvæð eða neikvæð er hún líkleg til að auka vitund um vörumerkið, hafa áhrif á ímynd pess (Bruhn, Schoenmueller og Schäfer, 2012) og hafa pannig áhrif á starfsemina hvort sem stjórnendum líkar pað betur eða verr (Kietzmann o.fl., 2011; Kwok og Yu, 2012).

\section{Virði vörumerkjasamfélaga fyrir neytendur}

Með tilkomu netsins og sér í lagi samfélagsmiðla hefur aðgengi neytenda að upplýsingum um vörur og pjónustu aukist verulega (Hsiao, Yeh og Tsai, 2013). Innan vörumerkjasamfélaga geta neytendur aflað sér upplýsinga um viðhorf og reynslu annarra neytenda enda gera samfélögin viðskiptavinum kleift á mun auðveldari máta en áður að deila reynslu sinni með öðrum mögulegum viðskiptavinum (Vinerean, Cetina, Dumitrescu og Tichindelean, 2013). Í stað pess að deila reynslu sinni auglitis til auglitis við einn eða nokkra í einu geta neytendur nú komið reynslu sinni á framfæri við jafnvel fleiri púsundir á einu augnabliki. Umfjallanir um reynslu af vörumerkjum eða samskiptum við fyrirtæki hafa áhrif á skoðanir annarra neytenda (Karakaya og Barnes, 2010) sem almennt telja pær upplýsingar trúverðugar enda eru pær taldar vera óhlutdrægar (O’Brien, 2011). Petta er mikil breyting fyrir fyrirtæki sem hingað til hafa að mestu leyti getað stjórnað pví hvaða upplýsingar neytendur hafa um vörumerki sín (Bruhn o.fl., 2012). Samfélagsmiðlar eru pannig að færa neytendum töluvert meiri völd en peir höfðu áður (Bruhn o.fl., 2012; Woodcock o.fl., 2011) og samfara pví hafa peir orðið kröfuharðari og væntingar peirra hafa aukist (O’Brien, 2011; Rosen og Phillips, 2011). Talið er líklegt að kröfur um skjóta svörun og viðbrögð við fyrirspurnum og athugasemdum sem beint er til fyrirtækja muni jafnvel aukast enn frekar (Rosen og Phillips, 2011). Allt petta hefur gjörbreytt sambandinu á milli fyrirtækja og neytenda (O'Brien, 2011).

Fyrirtæki verða að bjóða meðlimum vörumerkjasamfélagsins eitthvert virði gegn pví að fá hluta af tíma og athygli neytenda og pátttöku peirra í að halda síðunni virkri (Baird og Parasnis, 2011; Jahn og Kunz, 2012). Samskiptin á milli fyrirtækis og samfélagsmeðlima purfa að vera pannig að báðir gefi af sér og piggi eitthvað í staðinn (Gummerus o.fl., 2012; Jahn og Kunz, 2012; Ralphs, 2011). Leggja parf áherslu á virk og jákvæð samskipti sem skapa neytendum virði en ekki leggja ofuráherslu á að fjölga fylgjendum, enda skiptir litlu máli að hafa marga fylgjendur ef samfélagið er ekki virkt og ef pað veitir meðlimum pess ekki 
eitthvert virði (Alkhoms og Alnsour, 2013; Gummerus o.fl., 2012). Ef faglega er staðið að stjórnun vörumerkjasamfélagsins er talið að neytendur muni upplifa virði í að taka pátt í pví.

H1: Sterk vörumerkjasamfélög skapa virði fyrir neytendur.

Раð virði sem neytendur geta fengið út úr pátttöku í vörumerkjasamfélagi getur til dæmis verið í formi félagslegra tengsla við aðra meðlimi samfélagsins. Ef félagslegt tengslanet hefur myndast innan vörumerkjasamfélags felur pað í sér hegðun eins og að bjóða nýja meðlimi velkomna, styðja við bakið hver á öðrum og taka pátt í og ýta undir umræður meðal meðlimanna. Með pessu móti er ýtt undir tengsl milli meðlima samfélagsins og pað sem peir eiga sameiginlegt dregið fram (Schau, Muñiz og Arnould, 2009). Ef félagsleg tengsl hafa myndast milli meðlima verður til ákveðin sameiginleg vitund. Með sameiginlegri vitund er átt við að meðlimir samfélagsins finna fyrir tengingu við aðra meðlimi hvort sem peir pekkja pá persónulega eða ekki. Peir upplifa jafnframt einhvers konar mun á peim sem tilheyra viðkomandi samfélagi og hinum sem standa utan pess (Muñiz og O'Guinn, 2001). Eftir pví sem sameiginlega vitundin er sterkari, pví nánara er sambandið á milli meðlima og fyrirtækisins sjálfs. Pegar slíkt næst eru meðlimir samfélagsins líklegri til að taka virkan pátt í samfélaginu (Laroche, Habibi, Richard og Sankaranarayanan, 2012). Félagslegt tengslanet er líklegt til að myndast ef vel er staðið að stjórnun vörumerkjasamfélagsins af hálfu fyrirtækisins.

$\mathrm{H}_{1 a}$ : Sterk vörumerkjasamfélög skila neytendum virði í formi félagslegs tengslanets.

Pátttaka í samfélaginu felur í sér að vera virkur í pví sem par fer fram og jafnframt að ýta undir pátttöku annarra meðlima (Schau o.fl., 2009). Ef neytendur finna að peir hafa áhrif með pátttöku sinni, t.d. að hlustað sé á skoðanir peirra og ábendingar, getur pað veitt peim aukið virði. Peir eru í kjölfarið líklegri til að vera virkir í ýmsu sem tengist fyrirtækinu eða vörumerkinu. Peir taka pá gjarnan pátt í aðgerðum sem miða að pví að bæta pað sem parf að bæta hjá fyrirtækinu en slíkt getur reynst fyrirtækjum verulega dýrmætt (Sashi, 2012). Með faglegri stjórnun á vörumerkjasamfélagi geta fyrirtæki ýtt undir virka pátttöku meðlima pess sem síðan getur skapað peim ákveðið virði.

H1b: Sterk vörumerkjasamfélög skila neytendum virði í gegnum pátttöku peirra.

Prátt fyrir alla viðleitni fyrirtækis og annarra meðlima samfélagsins til að ýta undir pátttöku mun stærsti hluti meðlima einungis nota samfélagið sem uppsprettu upplýsinga, lesa pað sem birtist par en ekki taka virkan pátt með pví að skrifa eitthvað sjálfir eða líka við færslur annarra (Gummerus o.fl., 2012). Раð er talið að um 90\% notenda samfélagsmiðla skoði bara efni frá öðrum, 9\% bæti við pað efni til dæmis með pví að skrifa athugasemd en einungis $1 \%$ notenda búi til nýtt efni; setji inn færslu, mynd, myndband eða annað efni (Woodcock o.fl., 2011). Pó að margir meðlimir noti vettvanginn einungis sem upplýsingaveitu og tækifæri til að skiptast á skoðunum pá eru aðrir sem tengjast samfélaginu mun dýpri böndum. Samfélagið hefur mikla möguleika á að uppfylla parfir peirra einstaklinga og veita peim ánægju (Wilson og Morgan, 2011). 
Meðlimir vörumerkjasamfélaga geta að auki notið aukins virðis vegna peirra upplýsinga sem peir fá í gegnum aðra samfélagsmeðlimi. Ef samfélagið er virkt pá deila meðlimir gjarnan reynslu sinni af vörum og pjónustu og veita ýmis ráð varðandi notkun (Schau o.fl., 2009). Meðlimir geta deilt upplýsingum um pað sem hefur reynst peim vel í gegnum tíðina, t.d. varðandi pað hvar sé gott að kaupa aukahluti eða sækja pjónustu og jafnframt hvað eigi að forðast. Petta sparar öðrum meðlimum oft fyrirhöfn eða vandræði og geta meðlimir á pennan hátt lært af hver öðrum og pannig skapað betri upplifun af vörumerkinu, vörum pess og/eða pjónustu (Muñiz og O'Guinn, 2001). Meðlimir vörumerkjasamfélags sem fá tíðar og ítarlegar upplýsingar sem peir telja að skipti sig máli upplifa minni óvissu í tengslum við vörumerkið og fyrirtækið (Adjei o.fl., 2012).

\section{H1c: Sterk vörumerkjasamfélög skila neytendum virði í} gegnum upplýsingar frá öðrum meðlimum.

\section{Tryggð gagnvart fyrirtækjum og vörumerkjum}

Tryggð viðskiptavina getur veitt fyrirtækjum verulegan ávinning og forskot á markaði. Tryggir viðskiptavinir stunda viðskipti við fyrirtækið aftur og aftur (Odin, Odin og ValetteFlorance, 2001; Söderlund, 2006) og velja pað markvisst umfram önnur vörumerki/fyrirtæki (Söderlund, 2006). Vörumerkið sjálft er pví veigamikill páttur í valinu hjá tryggum viðskiptavinum (Odin o.fl., 2001) sem hafa ávallt áform um að halda viðskiptunum áfram (Bowen og Chen, 2001; McMullan, 2005). Par sem tryggir viðskiptavinir skipta síður yfir til samkeppnisaðila má segja að aukin tryggð dragi úr ógn af samkeppni (Ha, 2004; Rauyruen, Miller og Groth, 2009). Tryggð hefur einnig reynst hafa jákvæð áhrif á hagnað vegna lægri kostnaðar við markaðssetningu og lægri rekstrarkostnaðar (Bowen og Chen, 2001; Colgate og Norris, 2001; Reichheld og Sasser, 1990). Lægri rekstarkostnaður kemur aðallega til vegna pess að tryggir viðskiptavinir pekkja vörur, pjónustu og ferla fyrirtækisins og pví kostar alla jafna minna að pjónusta pá (Bowen og Chen, 2001; Colgate og Norris, 2001; Curasi og Kennedy, 2002; Mittal og Lasser, 1998; Reichheld og Sasser, 1990; Rust og Zahorik, 1993). Tryggð getur einnig leitt til meiri sölu en ella, enda kaupa tryggir viðskiptavinir almennt meira af fyrirtækinu en peir sem eru minna tryggir og peir eru ekki jafn verðnæmir (MartínConsuegra, Molina og Esteban, 2007; Rauyruen o.fl., 2009; Reichheld og Sasser, 1990; Srinivasan, Anderson og Ponnavolu, 2002). Auk pessa taka tryggir viðskiptavinir oft öflugan pátt í markaðssetningu með jákvæðu umtali um fyrirtækið, meðmælum og jafnvel ráðleggingum um ýmislegt er tengist vörum og pjónustu fyrirtækisins (Bowen og Chen, 2001; Reichheld og Sasser, 1990; Srinivasan o.fl., 2002). Af pessu má sjá að pað getur verið verulegur ávinningur í pví fyrir fyrirtæki að leggja áherslu á að auka tryggð viðskiptavina.

Traust er einn af lykilpáttum í uppbyggingu á tryggu langtíma sambandi sem bæði fyrirtæki og viðskiptavinir njóta ávinnings af (Alkhoms og Alnsour, 2013; Bauer, Grether og Leach, 2002). Traust felur í sér trú neytenda á að fyrirtækið/vörumerkið hafi langtíma hagsmuni viðskiptavinarins að leiðarljósi í aðgerðum sínum (Crosby, Evans og Cowles, 1990) og standi við pað sem lofað er (Chaudhuri og Holbrook, 2001) pannig að niðurstaðan verði jákvæð fyrir viðkomandi viðskiptavin (Bauer o.fl., 2002; Delgado-Ballester og MunueraAlemán, 2005). Heiðarleiki, hæfni, áreiðanleiki, öryggi og stöðugleiki eru eiginleikar sem verða að vera fyrir hendi hjá viðkomandi vörumerki svo hægt sé að byggja upp traust samband (Chaudhuri og Holbrook, 2001; Delgado-Ballester og Munuera-Alemán, 2005). Traust neytenda skapast ekki á einni nóttu heldur er pað ferli sem byggist á pví að fyrri 
reynsla viðskiptavinar hafi verið jákvæð pannig að hann komi aftur í viðskipti og að endingu fari að treysta vörumerkinu og sýna pví tryggð (Delgado-Ballester og Munuera-Alemán, 2005).

Eitt helsta markmið vörumerkjasamfélaga er að efla tengsl og auka tryggð gagnvart tilteknu vörumerki eða fyrirtæki (Laroche o.fl., 2012; Muñiz og O'Guinn, 2001; Schau o.fl., 2009). Samfélagsmiðlar gefa viðskiptavinum kost á að sjá mannlegri hlið á fyrirtækjum par sem persónuleiki peirra kemst til skila ef vel er að málum staðið (O’Brien, 2011). Pessi mannlega hlið auk peirra persónulegu og gagnvirku samskipta sem eiga sér stað auka líkur á sterkara sambandi sem ýtir undir traust og tryggð meðlima gagnvart fyrirtækinu (Gummerus o.fl., 2012; Laroche o.fl., 2012). Ef faglega er staðið að stjórnun vörumerkjasamfélaga ætti pað virði sem neytendur hljóta og hin ánægjulega upplifun að hafa jákvæð áhrif á tengsl neytenda við fyrirtækið/vörumerkið og ýta undir langtímasamband (Deepa og Deshmukh, 2013; Jahn og Kunz, 2012; Lilley, Grodzinsky og Gumbus, 2009; Vinerean o.fl., 2013).

$\mathrm{H}_{2}$ : Sterk vörumerkjasamfélög skila fyrirtækjum ávinningi í formi aukinnar tryggðar í gegnum pað virði sem skapast fyrir neytendur.

Sá félagslegi ávinningur sem getur hlotist af pátttöku í vörumerkjasamfélagi er talinn geta aukið ánægju og tryggð neytenda (Gummerus o.fl., 2012). Samfélagsmiðlar eru í eðli sínu félagslegur vettvangur og notendur peirra eru par í leit að tengslum, hvort sem pað eru tengsl við vini, kunningja, ættingja eða aðra hópa. Par sem forsenda notkunar neytenda á miðlunum er félagsleg er eðlilegt að gera ráð fyrir að æskilegast sé fyrir fyrirtæki að nýta pann hvata í samskiptum sínum við neytendur á peim vettvangi. Í rannsókn Gummerus o.fl. (2012) kom í ljós að skemmtun og félagslegur ávinningur eru peir pættir sem líklegastir eru til að auka tryggð meðlima vörumerkjasamfélags. Par kom jafnframt fram að neytendur sem fylgja fyrirtæki í kjölfar einhvers konar samkeppni eða happdrættis eru ekki tryggir til lengri tíma litið og ekki líklegri en aðrir til að eiga viðskipti við viðkomandi fyrirtæki.

$\mathrm{H}_{2 a}$ : Sterk vörumerkjasamfélög skila fyrirtækjum ávinningi í formi aukinnar tryggðar vegna pess virðis sem skapast fyrir neytendur í formi félagslegs tengslanets.

Pátttaka notenda er líkleg til að hafa jákvæð áhrif á samband peirra við viðkomandi vörumerki eða fyrirtæki hvort sem pátttakan felst í pví að líka við efni, koma með athugasemdir á færslur eða einfaldlega lesa pað sem aðrir hafa skrifað (Gummerus o.fl., 2012).

$\mathrm{H}_{2 b}$ : Sterk vörumerkjasamfélög skila fyrirtækjum ávinningi í formi aukinnar tryggðar vegna pess virðis sem skapast fyrir neytendur vegna pátttöku í samfélaginu.

Pær upplýsingar sem neytendur fá í gegnum pátttöku sína í vörumerkjasamfélagi draga úr áhættu og óvissu og eru par með líklegar til að auka traust á vörumerkinu og um leið tryggð gagnvart pví (Adjei o.fl., 2012; Laroche o.fl., 2012). Vegna peirra upplýsinga og 
reynslu sem aðrir meðlimir miðla innan samfélagsins geta aðilar lært hver af öðrum og pannig skapað betri upplifun af vörumerkinu (Muñiz og O'Guinn, 2001).

$\mathrm{H}_{2 b}$ : Sterk vörumerkjasamfélög skila fyrirtækjum ávinningi í formi aukinnar tryggðar vegna pess virðis sem skapast fyrir neytendur vegna upplýsinga sem miðlað er innan samfélagsins.

Á mynd 1 má sjá líkan rannsóknarinnar. Sterkt vörumerkjasamfélag sem er vel stjórnað er talið ýta undir aukið virði fyrir neytendur. Virðið felst í pví félagslega tengslaneti sem myndast innan vörumerkjasamfélaga, pátttöku meðlima í samfélaginu auk peirra upplýsinga sem miðlað er innan pess. Petta virði er svo talið auka tryggð neytenda við viðkomandi fyrirtæki eða vörumerki. Í líkaninu er pví gengið út frá pví að gagnkvæmur ávinningur hljótist af sterkum vörumerkjasamfélögum fyrir fyrirtæki og neytendur.

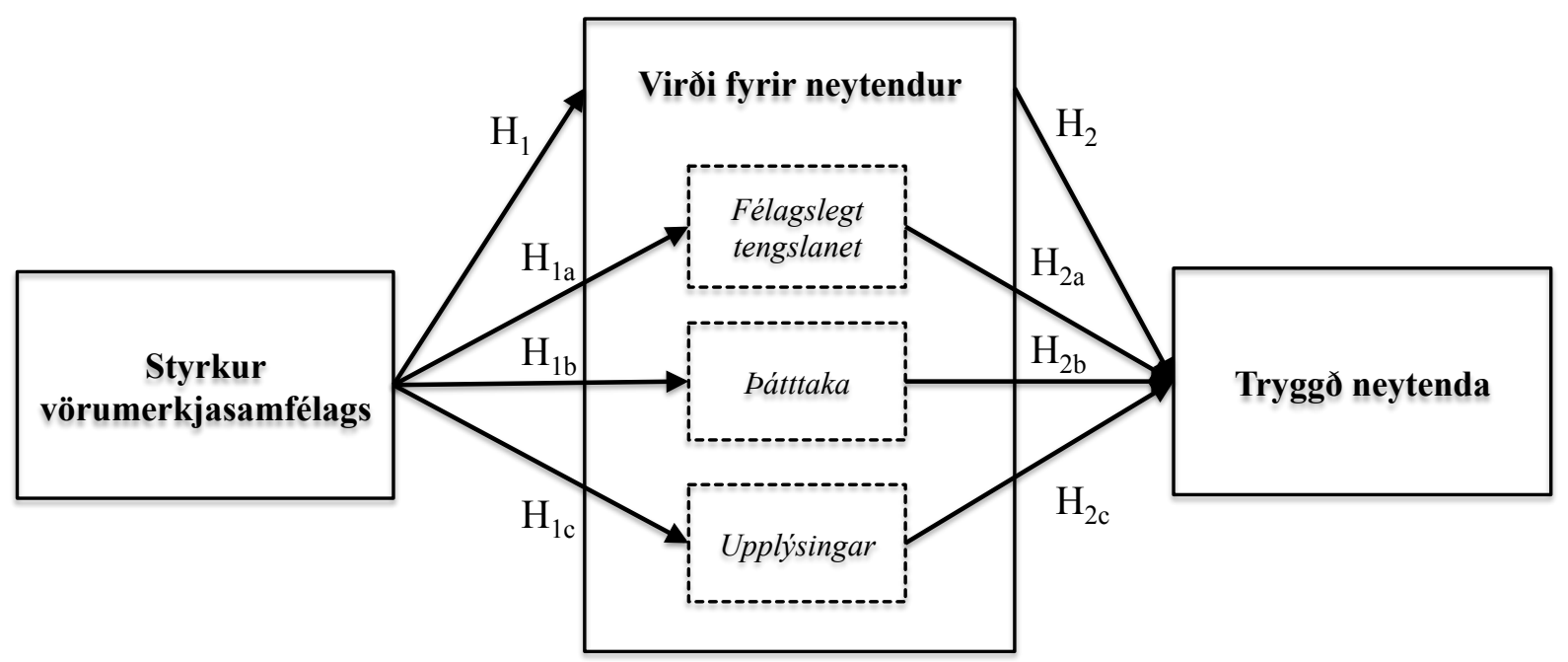

Mynd 1. Rannsóknarlíkanið

\section{Aðferð}

Markmið rannsóknarinnar var annars vegar að kanna hvort vörumerkjasamfélög geti skilað auknu virði fyrir neytendur í formi félagslegs tengslanets, áhuga á pátttöku og upplýsinga um notkun vörunnar/pjónustunnar. Hins vegar var markmiðið að kanna hvort vörumerkjasamfélög geti skapað ávinning fyrir fyrirtæki í formi aukinnar tryggðar viðskiptavina.

\subsection{Dátttakendur}

Notast var við tvær úrtaksaðferðir, rafrænt hentugleikaúrtak meðal nemenda Háskóla Íslands og snjóboltaúrtak í gegnum samfélagsmiðilinn Facebook. Internetið er í auknum mæli notað við fyrirlagnir á könnunum og er líklegt að pað verði enn algengara á komandi árum enda er talið að ókostirnir sem póttu fylgja peirri aðferð séu ekki lengur til staðar (sjá Hunter, 2012). Раð аð nota samfélagsmiðla við fyrirlagnir kannanna er ekki talin síðri leið við gagnaöflun með hentugleikaúrtaki, heldur jafnvel betri leið (Fang, Wen go Prybutok, 2014). Notkun Facebook við rafræna fyrirlögn er talin heppileg leið, sér í lagi pegar beita á snjóboltaúrtaki par sem svarhlutfall hefur reynst hærra með peirri aðferð heldur en pegar 
hefðbundnara rafrænu snjóboltaúrtaki er beitt (Baltar og Brunet, 2012). Jafnframt er algengt að samfélagsmiðlar séu notaðir við fyrirlögn á rannsóknum sem snúa að hegðun og viðhorfi á internetinu (sjá t.d. Bagozzi og Dholakia, 2006; Laroche o.fl., 2012; Steenkamp og Geyskens, 2006). Til að auka fjölda og margbreytileika pátttakenda var ákveðið að nýta ekki bara samfélagsmiðla við fyrirlögn heldur einnig fá pátttakendur úr hópi háskólanemenda.

Par sem rannsóknin snýr að vörumerkjasamfélögum var sett pað skilyrði fyrir pátttöku að fólk fylgdi/hefði líkað við einhverja síðu fyrirtækis eða vörumerkis á Facebook. Alls tóku 247 pátt í rannsókninni, par af voru töluvert fleiri konur (76,3\%) heldur en karlar (23,7\%). Pátttakendur voru margir í yngra lagi; 52,2\% voru yngri en 35 ára, 32,5\% á aldrinum 35 til 49 ára og 15,6\% eldri en 49 ára.

\subsection{Mælitæki}

Mælitækið samanstóð af premur undirkvörðum auk bakgrunnsspurninga. Fyrsti undirkvarðinn miðaði að mælingum á styrk vörumerkjasamfélags og samanstóð af 6 atriðum. Annar undirkvarðinn snéri að virði fyrir neytendur og samanstóð af 10 atriðum. Priðji undirkvarðinn mældi virði fyrir fyrirtækið í formi tryggðar neytenda og samanstóð af 5 atriðum. Áður en pátttakendur tóku afstöðu til fullyrðinga kvarðanna voru peir beðnir um að tilgreina eina síðu fyrirtækis eða vörumerkis sem peir fylgja eða hafa líkað við á Facebook. Síðan átti að uppfylla tvær forsendur; annars vegar átti hún að vera áberandi í fréttaveitu viðkomandi eða vera síða sem peir heimsækja reglulega og hins vegar átti hún að bjóða upp á skýrt vöru eða pjónustuframboð. Í kjölfarið voru pátttakendur beðnir að hafa viðkomandi síðu í huga við svörun listans.

Við samningu atriða varðandi styrk vörumerkjasamfélags var horft til rannsókna Hsieh, Chiu og Chiang (2005), Laroche o.fl. (2012) og Srinivasan o.fl. (2002). Pau sex atriði sem mynduðu undirkvarðann Styrkur vörumerkjasamfélags má sjá í töflu 1. Svarkostir voru á 5 punkta likert-kvarða par sem 1 merkti að pátttakendur væru mjög ósammála fullyrðingu og 5 merkti að pátttakendur væru mjög sammála fullyrðingu. Áreiðanleiki kvarðans reyndist ásættanlegur eins og sjá má í töflu 1.

Tafla 1. Undirkvarðinn Styrkur vörumerkjasamfélags

\begin{tabular}{l}
\hline Styrkur vörumerkjasamfélags: $\boldsymbol{\alpha}=\mathbf{0 , 7 5 7}$ \\
\hline Facebook síðan gefur notendum kost á að segja sína \\
skoðun eða að birta efni á síðunni \\
Viðskiptavinir deila reynslu sinni af vörum/pjóustu með \\
öðrum viðskiptavinum á síðunni \\
Síðan er gagnleg til að safna saman mismunandi \\
upplýsingum um vöruna eða vörumerkið \\
Meðlimir njóta góðs af pví að vera tengdir síðunni \\
Á síðunni eru veittar upplýsingar um vörur/pjónustu \\
Síðan er virk í að bæta við sig nýjum meðlimum \\
Síðan hvetur til umræðna um fyrirtækið, vörumerkið \\
eða vöruna \\
Meðlimir síðunnar taka virkan pátt í að byggja upp og \\
hlúa að uppbyggingu síðunnar
\end{tabular}


Kvarðinn Virði fyrir viðskiptavini samanstóð af premur páttum; félagslegu tengslaneti, pátttöku og upplýsingum. Við samningu atriða var horft til fyrri rannsókna. Atriði sem snéru að félagslegu tengslaneti voru fengin úr rannsóknum Laroche o.fl. (2012) og Srinivasan o.fl. (2002), atriði sem tengdust pátttöku voru fengin úr rannsókn Algesheimer o.fl. (2005) og atriði sem snéru að upplýsingum fengust úr rannsóknum Laroche o.fl. (2012) og Srinivasan o.fl. (2002). Áreiðanleiki kvarðans í heild reyndist góður ásamt áreiðanleika sérhvers páttar (sjá töflu 2). Svarkostir voru líkt og áður á 5 punkta likert-kvarða par sem 1 merkti að pátttakendur væru mjög ósammála fullyrðingu og 5 merkti að pátttakendur væru mjög sammála fullyrðingu.

Tafla 2. Undirkvarðinn Virði fyrir neytendur

\begin{tabular}{l}
\hline Virði fyrir neytendur: $\alpha=\mathbf{0 , 8 2 5}$ \\
\hline Félagslegt tengslanet: $\alpha=0,819$ \\
Meðlimir síðunnar eru mjög nánir hver öðrum \\
Meðlimir síðunnar finna fyrir nánum tengslum hver við \\
annan \\
Pátttaka: $\alpha=0,836$ \\
Ég er áhugasamur um að taka pátt í pví sem fram fer á \\
síðunni pví pað lætur mér líða vel \\
Ég er áhugasamur um að taka pátt í pví sem fram fer á \\
síðunni pví pannig get ég stutt aðra meðlimi \\
Ég er áhugasamur um að taka pátt í pví sem fram fer á \\
síðunni pví pað gerir mér kleift að ná persónulegum \\
markmiðum \\
Upplýsingar: $\alpha=0,773$ \\
Meðlimir síðunnar deila gagnlegum ábendingum \\
varðandi notkun vörunnar eða vörumerkisins \\
Meðilmir síðunnar deila reynslu sinni varðandi \\
árangursríkar eða misheppnaðar tillraunir sínar til að laga \\
vöruna/bjónstuna að sínum persónulegum börfum
\end{tabular}

Áreiðanleiki kvarðans Tryggð reyndist góður (sjá töflu 3). Við samningu atriða var horft til rannsókna Chaudhuri og Holbrook (2001) og Laroche o.fl. (2012). Svarkostir voru peir sömu og í hinum undirkvörðunum tveimur.

Tafla 3. Undirkvarðinn Tryggð

\begin{tabular}{l}
\hline Tryggð: $\boldsymbol{\alpha}=\mathbf{0 , 8 5 9}$ \\
\hline Ég tel mig tryggan vörumerkinu/fyrirtækinu \\
Ég er tilbúinn til að borga meira fyrir vörur/pjónustu \\
sem tilheyra vörumerkinu/fyrirtækinu en vörur/pjónustu \\
frá öðrum vörumerkjum/fyrirtækjum \\
Vörumerkið/fyrirtækið veitir mér allt pað sem ég er að \\
leita eftir í tilttekinni vöru/pjónustu \\
Ég treysti vörumerkinu \\
Vörumerkið/fyrirtækið veldur mér aldrei vonbrigðum \\
\hline
\end{tabular}


Spurningalistinn var forprófaður á sex einstaklingum á ólíkum aldri og af báðum kynjum til að kanna skilning. Smávægilegar athugasemdir komu fram í forprófun varðandi orðalag og var tekið tillit til peirra.

\subsection{Framkvæmd}

Spurningalistinn var settur upp með rafrænum hætti og var tengill á könnunina sendur í gegnum nemendaskrá Háskóla Íslands og í gegnum samfélagsmiðilinn Facebook. Annars vegar var notast við persónulega Facebook-reikninga höfunda og hins vegar var tengli á listann dreift í gegnum ýmsa hópa á Facebook.

Á upphafssíðu könnunarinnar var pátttakendum greint frá pví að rannsóknin snéri að vörumerkjum á samfélagsmiðlum. Óskað var eftir pátttöku fólks sem fylgdi eða hefði líkað við síðu fyrirtækis eða vörumerkis. Tekið var fram að svörun tæki í kringum 5 mínútur og að svör yrðu ekki rakin til pátttakenda. Söfnun gagna fór fram árið 2014.

\section{Niðurstöður}

Til að kanna tilgátu $\mathrm{H}_{1}$ var byrjað á að athuga hvort gögnin uppfylltu forsendur aðfallsgreiningar. Leifin sýndi að ekki var ástæða til að ætla að frávillingar (outliers) væru í gögnunum par sem 3,64\% af gildum stöðluðu leifarinnar voru hærri en tölugildið 2. Hins vegar virðist villan ekki vera normaldreifð heldur nokkuð skekkt til hægri par sem sjö gildi stöðluðu leifarinnar reyndust jákvæð en tvö neikvæð. Kolmogorov-Smirnov prófið sýndi að villuliðir væru normaldreifðir. Til að kanna hvort misdreifni væri í gögnunum var staðlaða leifin plottuð á móti spágildunum. Leifin dreifðist nokkuð jafnt yfir spágildin og pví var ekki ástæða til að ætla að misdreifni væri til staðar. Polið (tolerance) var 1,0 og VIF (variance inflation factor) var 1,0. Pví var ekkert sem benti til að marglínuleiki væri í gögnunum. Eina forsendan sem ekki var uppfyllt að fullu var forsendan um normaldreifða villuliði. Par sem aðrar forsendur voru uppfylltar var litið svo á að unnt væri að framkvæma aðfallsgreiningu, pó með pessum fyrirvara. Niðurstöður sýna að styrkur vörumerkjasamfélags spáir fyrir um pað heildarvirði sem skapast fyrir neytendur $(\beta=0,565)$. Heildaráhrif líkansins voru marktæk líkt og sjá má í töflu 4. Tilgáta $\mathrm{H}_{1}$ er pví studd.

Forsendur aðfallgreiningar voru kannaðar áður en athugað var hvort styrkur vörumerkjasamfélags spáði fyrir um pað félagslega tengslanet sem skapast fyrir neytendur. Gögnin uppfylltu forsendurnar utan forsendunnar um normaldreifða villuliði sem reyndust ögn jákvætt skekktir líkt og áður. Með sama fyrirvara og áður var talið ásættanlegt að kanna tilgátu $\mathrm{H}_{1 a}$ með aðfallsgreiningu. Niðurstöður sýna að styrkur vörumerkjasamfélags spáir fyrir um félagslegt tengslanet sem skapast fyrir neytendur $(\beta=0,248)$. Spágildið er pó ekki mjög hátt sem bendir til pess að aðrir pættir útskýri að miklu leyti félagslegt tengslanet. Engu að síður reyndist styrkur vörumerkjasamfélags spá fyrir um félagslegt tengslanet og er pví tilgáta $\mathrm{H}_{1 a}$ studd.

Sama var uppi á teningnum varðandi tilgátur $\mathrm{H}_{1 \mathrm{~b}}$ og $\mathrm{H}_{1 \mathrm{c}}$. Forsendur voru uppfylltar að öðru leyti en pví að villuliðir væru normaldreifðir. Í tilfelli forspárgildis vörumerkjasamfélags varðandi pátttöku reyndust villuliðir jákvætt skekktir eins og áður en í tilfelli forspárgildis varðandi upplýsingar reyndust peir neikvætt skekktir. Líkt og áður var ákveðið að halda áfram með aðfallsgreiningu en túlka niðurstöður með pessum fyrirvara. Niðurstöður sýna að styrkur vörumerkjasamfélags spáir fyrir um pátttöku meðlima $(\beta=$ $0,457)$. Tilgáta $\mathrm{H}_{1 \mathrm{~b}}$ er pví studd. Styrkur vörumerkjasamfélags reyndist jafnframt spá fyrir um virði peirra upplýsinga sem miðlað er $(\beta=0,602)$. Tilgáta $\mathrm{H}_{1 c}$ er pví studd. 
Tafla 4. Heildaráhrif og skýringarmáttur líkana sem snúa að forspárgildi vörumerkjasamfélags varðandi virði fyrir neytendur

\begin{tabular}{lllc}
\hline \multicolumn{1}{c}{ Óháð breyta } & \multicolumn{1}{c}{ Háðar breytur } & \multicolumn{1}{c}{ ANOVA $^{\mathbf{b}}$} & $\mathbf{R}^{\mathbf{2}}$ \\
\hline \multirow{3}{*}{ Styrkur } & Virði fyrir neytendur & $F(1,222)=103,89 ; p<0,001$ & 0,319 \\
vörumerkja- & Félagslegt tengslanet & $F(1,229)=15,03 ; p<0,001$ & 0,062 \\
samfélags & Pátttaka & $F(1,224)=59,28 ; p<0,001$ & 0,209 \\
& Upplýsingar & $F(1,229)=130,36 ; p<0,001$ & 0,363 \\
\hline
\end{tabular}

Forsendur aðhvarfsgreiningar voru uppfylltar við athugun á H2. Niðurstöður sýna að styrkur heildarvirðis fyrir viðskiptavini spáir fyrir um tryggð peirra gagnvart fyrirtækinu eða vörumerkinu $(\beta=0,421)$. Heildaráhrif líkansins reyndust marktæk líkt og sjá má á töflu 5. Tilgáta $\mathrm{H}_{2}$ er pví studd.

Við athugun á tilgátum $\mathrm{H}_{2 a}, \mathrm{H}_{2 b}$ og $\mathrm{H}_{2 c}$ reyndust forsendur aðhvarfsgreiningar uppfylltar. Niðurstöður leiddu í ljós að pað virði sem hlýst af pátttöku $(\beta=0,337)$ og upplýsingum $(\beta=0,193)$ vegna aðildar að vörumerkjasamfélagi spáir fyrir um tryggð en pað virði sem hlýst af félagslegu tengslaneti spáir ekki fyrir um tryggð $(\beta=-0,025)$. Heildaráhrif líkansins reyndust marktæk $(F(3,226)=18,37 ; p<0,001)$ og reyndist dreifing breytanna skýra $19,6 \%$ af dreifingu tryggðar. Tilgátur $\mathrm{H}_{2 a}$ og $\mathrm{H}_{2 b}$ eru pví studdar en ekki tilgáta $\mathrm{H}_{2 c}$.

Tafla 5. Heildaráhrif og skýringarmáttur líkana sem snúa að forspárgildi virðis fyrir neytendur varðandi tryggð gagnvart fyrirtæki eða vörumerki

\begin{tabular}{lccc}
\hline \multicolumn{1}{c}{ Óháðar breytur } & Háð breyta & ANOVA $^{\mathbf{b}}$ & $\mathbf{R}^{2}$ \\
\hline Virði fyrir neytendur & & $F(1,228)=48,98 ; p<0,001$ & 0,177 \\
Félagslegt tengslanet & $\begin{array}{c}\text { Tryggð } \\
\text { neytenda }\end{array}$ & $F(3,226)=18,37 ; p<0,001$ & 0,196 \\
$\begin{array}{l}\text { Pátttaka } \\
\text { Upplýsingar }\end{array}$ & & & \\
\hline
\end{tabular}

Á mynd 2 má sjá niðurstöður rannsóknarlíkansins settar fram á myndrænan hátt.

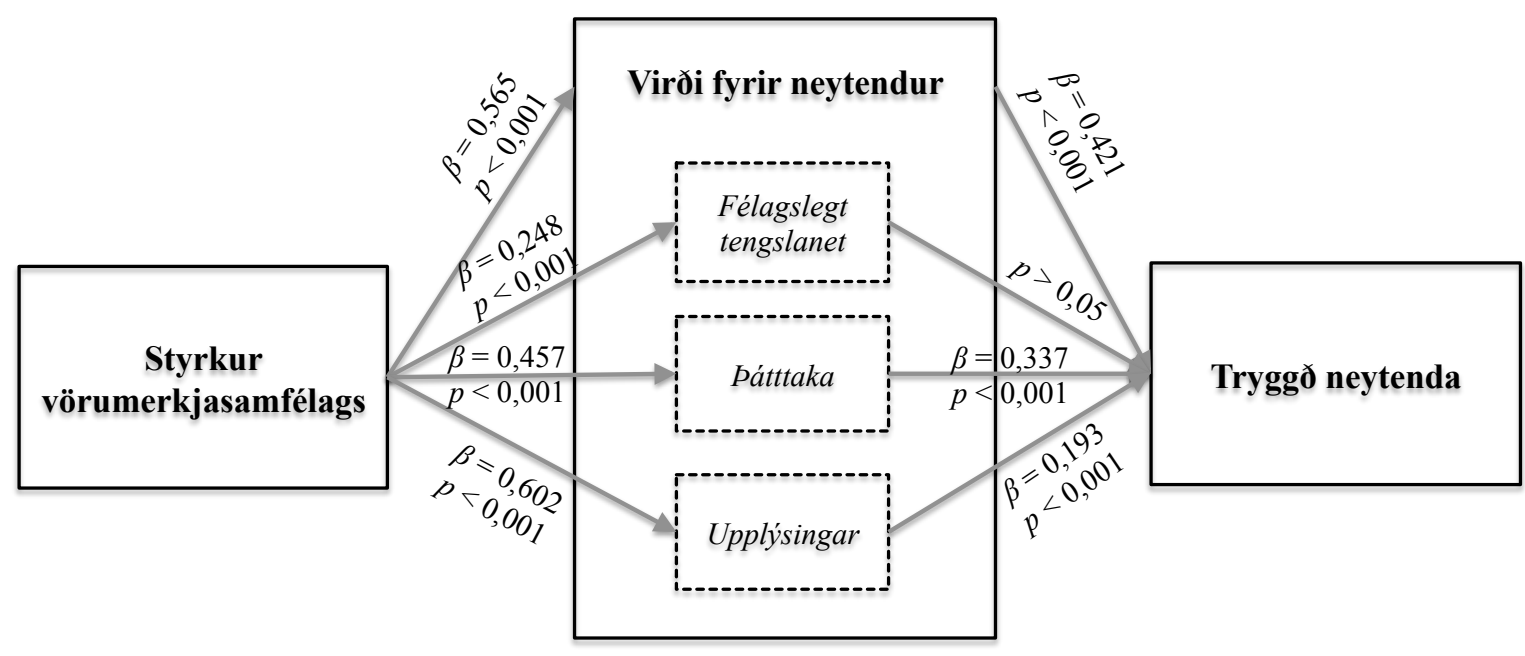

Mynd 2. Niðurstöður rannsóknarlíkansins 
Athugað var hvort pað virði sem skapast fyrir neytendur af vörumerkjasamfélögum sé ástæða aukningar tryggðar neytenda eða hvort sterkt vörumerkjasamfélag eitt og sér leiði með beinum hætti til aukinnar tryggðar. Pví voru tengsl vörumerkjasamfélags við tryggð könnuð með virði fyrir neytendur sem miðlunarbreytu. Eftirfarandi forsendur voru uppfylltar:

- Styrkur vörumerkjasamfélags spáir fyrir um tryggð $\left(F(1,226)=58,63 ; p<0,001 ; R^{2}\right.$ $=0,206 ; \beta=0,454)$.

- Styrkur vörumerkjasamfélags spáir fyrir um virði fyrir neytendur $(F(1,222)=$ 101,$\left.89 ; p<0,001 ; R^{2}=0,319 ; \beta=0,565\right)$.

- Virði fyrir viðskiptavini spáir fyrir um tryggð neytenda $(F(1,228)=48,98 ; p<$ 0,$\left.001 ; R^{2}=0,177 ; \beta=0,421\right)$.

Pegar bæði styrkur vörumerkjasamfélags og virði fyrir neytendur voru sett inn í líkanið til að kanna forspárgildið fyrir tryggð reyndist skýringarmáttur styrks vörumerkjasamfélags á tryggð minnka. Útskýringarmátturinn fór úr $\beta=0,454$ í $\beta=0,295$. Útskýringarmátturinn hélst hins vegar marktækur og pví er ljóst að virði fyrir viðskiptavini er að hluta til miðlari (en ekki að fullu miðlari) milli styrks vörumerkjasamfélags og tryggðar.

\section{$7 \quad$ Umræða}

Neytendur eru á samfélagsmiðlum og nýta pann rafræna heim í miklum mæli í alls kyns félagsleg samskipti (Alkhoms og Alnsour, 2013). Á síðustu árum hafa fleiri og fleiri fyrirtæki kosið að nálgast neytendur í pessum rafræna heimi með pví að skapa vörumerkjasamfélög. Par geta fyrirtækin haft bein samskipti við neytendur en eru um leið að bjóða upp á vettvang til að peir geti átt samskipti sín í milli. Hvort sem starfsfólk innan fyrirtækjanna sér um vörumerkjasamfélögin eða útvistar peirri vöktun til annarra fyrirtækja pá er ljóst að pað kallar á fjárútlát af hálfu fyrirtækja að halda úti vörumerkjasamfélögum. Pað er pví full ástæða til að rannsaka til hlítar hvort sú fjárfesting sé líkleg til að skila fyrirtækjum ávinningi. Markmið rannsóknarinnar var annars vegar að kanna hvort vörumerkjasamfélög séu líkleg til að skila neytendum ávinningi og hins vegar hvort pau séu líkleg til að skila fyrirtækjum ávinningi í gegnum mögulegan ávinning neytenda.

Niðurstöðurnar sýna að sterkt vörumerkjasamfélag par sem upplýsingum er miðlað og ýtt er undir pátttöku meðlima skapar virði fyrir neytendur. Félagslegt tengslanet peirra styrkist, peir upplifa ávinning af pátttöku og sjá gagn í peim upplýsingum sem miðlað er innan samfélagsins. Líkt og kemur fram í rannsóknum bæði Alkhoms og Alnsour (2013) og Gummerus o.fl. (2012) ættu fyrirtæki pví fyrst og fremst að leggja kapp á virk samskipti bæði við neytendur en einnig neytenda í milli, en ekki leggja ofuráherslu á að fjölga fylgjendum líkt og stundum má sjá hjá fyrirtækjum með ýmiss konar „líka og deila“-leikjum. Neytendur sem líka við síður fyrirtækja í kjölfar einhvers konar leikja sem eiga að stuðla að fjölgun fylgjenda eru ekki líklegri en aðrir til að eiga viðskipti við fyrirtækið og eru ekki taldir tryggir til lengri tíma (Gunnerus o.fl., 2012). Prátt fyrir að pað kunni að vera líklegt að slíkir leikir auki vitund um fyrirtækið eða vörumerkið er mikilvægt að hafa forgangsröðunina á hreinu pegar kemur að stjórnun vörumerkjasamfélaga. Par ætti aukin virkni og áhersla á jákvæð samskipti við meðlimi samfélagsins að vera í forgrunni.

Niðurstöðurnar sýna að virðið sem neytendur njóta vegna vörumerkjasamfélagsins leiðir til aukinnar tryggðar peirra gagnvart viðkomandi fyrirtæki eða vörumerki. Aukning í 
tryggð myndast ekki bara vegna styrks samfélagsins heldur í gegnum pað virði sem skapast fyrir neytendur. Pær tilgátur sem settar voru fram í rannsókninni voru studdar fyrir utan eina. Sú tilgáta snéri að pví að pað virði sem hlýst af félagslegu tengslaneti vegna vörumerkjasamfélaga stuðli að tryggð gagnvart viðkomandi vörumerki eða fyrirtæki. Sú niðurstaða er í andstöðu við niðurstöðu Gummerus o.fl. (2012). Petta er pví páttur sem nauðsynlegt er að kanna betur í frekari rannsóknum. Ekki má horfa framhjá pví að virði getur skapast vegna félagslega tengslanetsins fyrir neytendur sem er pví ávinningur fyrir neytendur. En miðað við niðurstöður pessarar rannsóknar njóta fyrirtæki ekki ávinnings af pví í formi aukinnar tryggðar.

Pessar niðurstöður eru veigamiklar fyrir fyrirtæki og mikilvægt framlag til fræðanna um stjórnun vörumerkjasamfélaga. Líkt og í öðru markaðsstarfi sést hér að útgangspunkturinn parf fyrst og fremst að vera viðskiptavinurinn og pað virði sem skapað er fyrir hann. Sé hugað að auknu virði fyrir viðskiptavini í gegnum pátttöku í vörumerkjasamfélagi leiðir pað til ávinnings fyrir fyrirtæki í formi aukinnar tryggðar. Fyrri rannsóknir hafa sýnt fram á ýmiss konar ávinning af pví að leggja áherslu á tryggð viðskiptavina (sjá t.d. Bowen og Chen, 2001; Colgate og Norris, 2001; Curasi og Kennedy, 2002; Ha, 2004; Rauyruen, Miller og Groth, 2009; Reichheld og Sasser, 1990). Pessar niðurstöður sýna okkur pví að pað er gagnkvæmur ávinningur fyrir neytendur og fyrirtæki af pví að halda úti sterkum vörumerkjasamfélögum. Sú fjárfesting að nýta krafta starfsfólks til að halda úti öflugum vörumerkjasamfélögum er pví líkleg til að skila jákvæðri fjárhagslegri niðurstöðu fyrir fyrirtæki.

Vissulega er í öllum tilfellum ákjósanlegra að beita líkindaúrtaki við fyrirlögn kannana. Hins vegar er afar algengt að hentugleikaúrtaki sé beitt við rannsóknir innan markaðsfræði og var talið ásættanlegt að gera pað í pessu tilviki. Reynt var að leggja áherslu á að fá fjölbreyttan hóp fólks til að taka pátt með pví að nýta bæði póstlista háskólanemenda og einnig samfélagsmiðilinn Facebook við fyrirlögn. Dreifing pátttakenda eftir kyni og aldri var pó ekki jafn góð og vonast var eftir par sem töluvert fleiri konur tóku pátt en karlar auk pess sem meirihluti pátttakenda var nokkuð ungur. Рað er pví ekki hægt að segja að pátttakendur endurspegli fyllilega notendur samfélagsmiðla. Pessi annmarki kann vissulega að hafa áhrif á niðurstöður rannsóknarinnar og ber að líta á pær með peim fyrirvara. Í frekari rannsóknum væri pví ákjósanlegt að leggja aukna áherslu á að ná í úrtak sem endurspeglar pýðið með betri hætti.

Líklegt má telja að pað sé misjafnt eftir eðli starfsemi fyrirtækja hversu fýsilegt og líklegt til árangurs pað sé að halda úti vörumerkjasamfélögum. Hvers konar starfsemi er líkleg til að geta náð fram miklum ávinningi með virkri og faglegri stjórnun vörumerkjasamfélaga og hvers konar starfsemi er ekki líkleg til að njóta góðs af slíku? Svör við pessu væri ákjósanlegt fyrir fyrirtæki að fá í frekari rannsóknum. İ dag virðist raunin stundum vera sú að fyrirtæki stofna síður á samfélagsmiðlum án pess að setja sér skýr markmið og án pess að vita í raun hver ávinningurinn af pví kunni að vera. Stundum virðist sem svo að slíkar síður séu stofnaðar vegna pess að „allir aðrir eru að gera pað“. Slíkt er vitanlega ekki ákjósanlegt í rekstri fyrirtækja enda kallar utanumhald og stjórnun pessara síðna á fjárútlát af hálfu fyrirtækja. •að er pví ákjósanlegt að fyrirtæki í hinum ýmsu greinum fái betri upplýsingar um pað hvort pað sé líklegt til að skapa fyrirtækinu aukinn ávinning að halda úti vörumerkjasamfélögum. Samanburður á líklegum ávinningi fyrirtækja innan ólíkra greina væri pví ákjósanlegt næsta skref í rannsóknum á mögulegum ávinningi pess fyrir neytendur og fyrirtæki að fyrirtæki haldi úti vörumerkjasamfélögum. 


\section{Heimildir}

Adjei, M. T., Noble, C. H. og Noble, S. M. (2012). Enhancing relationships with customers through online brand communities. MIT Sloan Management Review, 53(4), 22-24

Alkhoms, A. og Alnsour, M. S. (2013). Social media marketing and relationship quality: Zain Jordan customers' perspective. European Journal of Business and Management, 5(25), 111117.

Ang, L. (2011). Community relationship management and social media. Journal of Database Marketing \& Customer Strategy Management, 18(1), 31-38.

Bagozzi, R. og Dholakia, U. (2006). Open source software communities: A study of participation in Linux user groups. Management Science, 52, 1099-1115.

Baird, C. H. og Parasnis, G. (2011). From social media to social customer relationship management. Strategy \& Leadership, 39(5), 30-37

Baltar, F. og Brunet, I. (2012). Social research 2.0: Virtual snowball sampling method using Facebook. Internet Research, 22(1), 57-74.

Bauer, H. H., Grether, M. og Leach, M. (2002). Building customer relations over the Internet. Industrial Marketing Management, 31(2), 155-163.

Bowen, J. T. og Chen, S.-L. (2001). The relationship between customer loyalty and customer satisfaction. International Journal of Contemporary Hospitality Management, 13(5), 213-217.

Bruhn, M., Schoenmueller, V. og Schäfer, D. B. (2012). Are social media replacing traditional media in terms of brand equity creation? Management Research Review, 35(9), 770-790.

Chaudhuri, A. og Holbrook, M. B. (2001). The chain of effects from brand trust and brand affect to brand performance: The role of brand loyalty. Journal of Marketing, 65(2), 81-93.

Colgate, M. og Norris, M. (2001). Developing a comprehensive picture of service failure. International Journal of Service Industry Management, 12(3), 215-233.

Crosby, L. A., Evans, K. R. og Cowles, D. (1990). Relationship quality in services selling: An interpersonal influence perspective. Journal of Marketing, 54(3), 68-81.

Cursai, C. F. og Kennedy, K. N. (2002). From prisoners to apostles: A typology of repeat buyers and loyal customers in service business. The Journal of Service Marketing, 16(4), 322-341

Deepa, N. og Deshmukh, S. (2013). Social media marketing: The next generation of business engagement. International Journal of Management Research and Reviews, 3(2), 2461-2468.

Dekay, S. H. (2012). How large companies react to negative Facebook comments. Corporate Communications: An International Journal, 17(3), 289-299.

Delgado-Ballester, E. og Munuera-Alemán, J. L. (2005). Does brand trust matter to brand equity? The Journal of Product and Brand Management, 14(2/3), 187-196.

Edosomwan, S., Prakasan, S. K., Kouame, D., Watson, J. og Seymour, T. (2011). The history of social media and its impact on business. Journal of Applied Management and Entrepreneurship, 16(3), 79-91.

Fang, J., Wen, C. Og Prybutok, V. (2014). An assessment of equivalence between paper and social media surveys: The role of social desirability and satisficing. Computers in Human Behavior, 30, 335-343.

Gummerus, J., Liljander, V., Weman, E. og Pihlström, M. (2012). Customer engagement in a Facebook brand community. Management Research Review, 35(9), 857-877

Ha, H.-Y. (2004). Factors influencing consumer perceptions of brand trust online. The Journal of Product and Brand Management, 13(4/5), 329-342. 
Hanna, R., Rohm, A. og Crittenden, V. L. (2011). We're all connected: The power of the social media ecosystem. Business Horizons, 54(3), 265-273.

Hsiao, C.-H., Yeh, S.-S. og Tsai, C.-F. (2013). The impact of self-complexity on attitudes towards online marketing and buying intentions: Using the internet addiction as a moderator. Xing Xiao Ping Lun, 10(1), 79-102.

Hsieh, C., Chiu, H.-C. Og Chiang, M.-Y. (2005). Maintaining a committed online customer: A study across search-experience-credence products. Journal of Retailing, 81(1), 75-82.

Hunter, L. (2012). Challenging the reported disadvantages of e-questionnaires and addressing methodological issues of online data collection. Nurse Researcher, 20(1), 11-20.

Jahn, B. og Kunz, W. (2012). How to transform consumers into fans of your brand. Journal of Service Management, 23(3), 344-361.

Karakaya, F. og Barnes, N. G. (2010). Impact of online reviews of customer care experience on brand or company selection. Journal of Consumer Marketing, 27(5), 447-457.

Kietzmann, J. H., Hermkens, K., McCarthy, I. P. og Silvestre, B. S. (2011). Social media? Get serious! Understanding the functional building blocks of social media. Business Horizons, 54(3), 241-251.

Kwok, L. og Yu, B. (2012). Spreading social media messages on Facebook: An analysis of restaurant business-to-consumer communications. Cornell Hospitality Quarterly, 54(1), 84-94.

Laroche, M., Habibi, M. R., Richard, M.-O. og Sankaranarayanan, R. (2012). The effects of social media based brand communities on brand community markers, value creation practices, brand trust and brand loyalty. Computers in Human Behavior, 28(5), 1755-1767.

Lee, H. S. (2013). Social media and youtube as an attractive marketing tool. Journal of American Business Review, Cambridge, 1(2), 249-255.

Lilley, S., Grodzinsky, F. S. og Gumbus, A. (2009). Revealing the commercialized and compliant Facebook user. Journal of Information, Communication and Ethics in Society, 10(2), 82-92.

Martín-Consuegra, D., Molina, A. og Esteban, Á. (2007). An integrated model of price, satisfaction and loyalty. An empirical analysis in the service sector. Journal of Product $\mathcal{E}$ Brand Management, 16(7), 459-468

McCorkindale, T. (2010). Can you see the writing on my wall? A content analysis of the fortune 50's Facebook social networking sites. Public Relations Journal, 4(3), 1-14.

McMullan, R. (2005). A multiple-item scale for measuring customer loyalty development. The Journal of Service Marketing, 19, 470-481.

Mittal, B. og Lasser, W. M. (1998). Why do customer switch? The dynamics of satisfaction versus loyalty. Journal of Service Marketing, 12(3), 177-194.

Muñiz, A. M. og O'Guinn, T. C. (2001). Brand community. Journal of Consumer Research, 27(4), 412-432.

O'Brien, C. (2011). The emergence of the social media empowered consumer. Irish Marketing Review, 21(1/2), 32-40.

Odin, Y., Odin, N. og Valette-Florence, P. (2001). Conceptual and operational aspects of brand loyalty. An empirical investigation. Journal of Business Research, 53(2), 75-84.

Pöyry, E., Parvinen, P. og Malmivaara, T. (2013). Can we get from liking to buying? Behavioral differences in hedonic and utilitarian Facebook usage. Electronic Commerce Research and Applications, 12(4), 224-235.

Ralphs, M. (2011). Built in or bolt on: Why social currency is essential to social media marketing. Journal of Direct, Data and Digital Marketing Practice, 12(3), 211-215. 
Rauyruen, P., Miller, K. E. og Groth, M. (2009). B2B services: Linking service loyalty and brand equity. Journal of Service Marketing, 23(3), 175-186.

Reichheld, F F. og Sasser, W. E. (1990). Zero defections: Quality comes to services. Harvard Business Review, 68(5), 105-111.

Reinartz, W., Krafft, M og Hoyer, W. D. (2004). The customer relationship management process: Its measurement and impact on performance. Journal of Marketing Research, 41(3), 293-305.

Rosen, P. A. og Phillips, M. H. (2011). Marketing and the rise of web 2.0: Expanding opportunity, increasing challenge. The Review of Business Information Systems, 15(3), 3542.

Rust, R. T. og Zahoric, A. J. (1993). Customer satisfaction, customer retention, and market share. Journal of Retailing, 69(2), 193-215.

Sashi, C. M. (2012). Customer engagement, buyer-seller relationships, and social media. Management Decision, 50(2), 253-272.

Schau, H. J., Muñiz, A. M. og Arnould, E. J. (2009). How brand community practices create value. Journal of Marketing, 73(5), 30-51.

Schmidt, S. M. P. og Ralph, D. L. (2011). Social media: More available marketing tools. The Business Review, Cambridge, 18(2), 37-43.

Srinivasan, S. R., Anderson, R. Og Ponnavolu, K. (2002). Customer loyalty in e-commerce: An exploration of its antecedents and consequences. Journal of Retailing, 78(1), 41-50.

Steenkamp, J.B.E.M. og Geyskens, I. (2006). How country characteristics affect the perceived value of a website. Journal of Marketing, 70, 136-150.

Söderlund, M. (2006). Measuring customer loyalty with multi-item scales. A case for caution. Journal of Service Management, 17(1), 76-98.

Vinerean, S., Cetina, I., Dumitrescu, L. og Tichindelean, M. (2013). The effects of social media marketing on online consumer behavior. International Journal of Business and Management, 8(14), 66-79.

Vorvoreanu, M. (2009). Perceptions of corporations on Facebook: An analysis of Facebook social norms. Journal of New Communications Research, 4(1), 67-86.

Wilson, J. A. og Morgan, J. E. (2011). Friends or freeloaders? Encouraging brand conscience and introducing the concept of emotion-based consumer loss mitigation. Journal of Brand Management, 18(9), 659-676.

Woodcock, N., Green, A. og Starkey, M. (2011). Social CRM as a business strategy. Journal of Database Marketing \& Customer Strategy Management, 18(1), 50-64.

Wright, E., Khanfar, N. M., Harrington, C. og Kizer, L. E. (2010). The lasting effects of social media trends on advertising. Journal of Business E Economics Research, 8(11), 73-80. 